\title{
Application of Contemporary Extraction Techniques for Elements and Minerals Recovery from Stinging Nettle Leaves
}

\author{
Saša Popov ${ }^{1,2}{ }^{2}$, Suzana Skeledžija ${ }^{1}$, Saša Šorgić ${ }^{1}$, Zoran Zeković $^{3}$, Darko Micić $^{4}{ }^{\oplus}$, \\ Aleksandra Radulović ${ }^{4}$ and Saša Đurović ${ }^{4, * \mathbb{B}}$ \\ 1 Oenological laboratory, Heroja Pinkija 49, 26300 Vršac, Serbia; sasa.popov123@gmail.com (S.P.); \\ suzanasuzas@gmail.com (S.S.); sasasorgic@gmail.com (S.Š.) \\ 2 MS Enviro, Njegoševa 22, 26300 Vršac, Serbia \\ 3 Faculty of Technology, University of Novi Sad, Bulevar Cara Lazara 1, 21000 Novi Sad, Serbia; \\ zzekovic@tf.uns.ac.rs \\ 4 Institute of General and Physical Chemistry, University of Belgrade, Studentski trg 12/V, 11158 Belgrade, \\ Serbia; micic83@gmail.com (D.M.); aradulovic@iofh.bg.ac.rs (A.R.) \\ * Correspondence: sasatfns@uns.ac.rs; Tel.: +381-65-95-77-200
}

Received: 4 December 2019; Accepted: 16 January 2020; Published: 22 January 2020

\begin{abstract}
Stinging nettle (Urtica dioica L.) is a perennial plant belonging to the Urticaceae family. Several studies have reported the presence of the different classes of chemical compounds, which expressed a beneficial effect on human health. Among them there are elements and minerals that are essential for the proper functioning of organism. Mineral occurrence requires analytical data about the content. For such purposes was developed and validated a method based on the optical emission spectroscopy coupled with inductively coupled plasma (ICP-OES). Minerals and elements were extracted using two conventional methods (Soxhlet and maceration) and two non-conventional (ultrasound- and microwave-assisted techniques). The extracts were analyzed resulting in high diversity in the composition. Non-conventional techniques showed better results, since those extracts possessed high content of the macroelements and iron as well, instead the toxic elements were found in trace amount
\end{abstract}

Keywords: stinging nettle; extracts; minerals; ICP-OES analysis; method validation

\section{Introduction}

Stinging nettle (Urtica dioica L.) is a perennial plant from the Urticaceae botanical family. This plant is widely distributed and native to Europe, Asia, North Africa, and North America. It is known for its application in folk medicine, where it has been used for the treatment of various diseases and disorders [1,2]. Recent studies have shown the presence of different classes of compounds, e.g., terpenoids [3,4], carotenoids [3,5,6], fatty acids [2,3,6-8], phenolic, and polyphenolic compounds [1,3,9-11], amino acids, chlorophyll, vitamin C, vitamin $K$, vitamins B series, tannins, carbohydrates, sterols, polysaccharides, isolectins [1,3,5,12], as well as minerals $[3,13,14]$. It is worth mentioning that stinging nettle is very rich in iron (leaves contain about $150 \mathrm{mg} / \mathrm{kg}$ ), while some important fatty acids, e.g., palmitic, cis-9,12 linoleic and a-linolenic acids, are also detected [3].

The chemical profile of the stinging nettle's leaves explains the wide range of biological activity. It has also been reported that this plant shows antioxidant, anti-microbial, anti-inflammatory, anti-ulcer, cytotoxic, and analgesic properties [5,11,15-17]. Thus, a long history of the application of stinging nettle in folk medicine is more than justified. Moreover, stinging nettle leaves have found a role in the kitchen. It has been applied for the preparation of different dishes, e.g., soups, rice dishes, in 
combination with noodles, omelets or scrambled eggs or as a salad, and in the preparation of herbal liquors [18].

Application of the herbs and their extracts are more and more attractive in a modern world. Possibilities of the applications are almost unlimited, starting from the pharmaceutical industry, through food and beverages to the everyday application in agriculture, and many others. To be used in the above-mentioned fields, the plant and/or its extracts need to meet certain requirements regarding safety and toxicity. Minerals need to be recovered from their sources as much as possible to satisfy the daily needs of the human organism. Taking into account the importance of this plant, as well as its chemical composition, this study aims to develop a method for determination of the minerals in the extracts of stinging nettle leaves, and their analysis by inductively coupled plasma optical emission spectroscopy (ICP-OES). Several extraction techniques (conventional and nonconventional) were applied in order to recover metals and minerals from stinging nettle leaves. Additionally, the presence of mercury was also investigated using a direct mercury analyzer (DMA). Obtained results were statistically analyzed and certain conclusions were drawn.

\section{Materials and Methods}

\subsection{Chemicals and Reagents}

Cadmium, copper, zinc, lead, nickel, iron, manganese, potassium, sodium calcium, magnesium, and mercury standards were purchased from Merck (Darmstadt, Germany). All other chemicals were of analytical grade.

\subsection{Plant Material}

Stinging nettle (Urtica dioica L.) leaves were collected in Vršac area (Southeastern Banat, Autonomous Province of Vojvodina, Republic of Serbia) during the period of April-May in 2015. Voucher specimens (Urtica dioica L., Vršac area, legator and determiner Saša Đurović, N ${ }^{\circ} 2-1539$ ) are deposited at the Herbarium BUNS, University of Novi Sad, Faculty of Science, Department of Biology and Ecology. Leaves were dried naturally in the shade on draft for one month. Dried plant material was grounded in the blender and kept in paper bags before its usage.

\subsection{Sample Preparation for Elemental Analysis}

For extraction of stinging nettle (SN) leaves, Soxhlet (SE), maceration (MAC), ultrasound-assisted (UAE), and microwave-assisted (MAE) techniques were used. Extracts were prepared according to the previously described procedures [19]. Solvent for all extraction techniques was distilled water, with the exception of Soxhlet extraction, where $96 \%$ ethanol was used. Certain volume of the extracts was further mixed with concentrated nitric acid and water in a ratio that provided a concentration of $1 \%$ of $\mathrm{HNO}_{3}$ in the final mixture for analysis.

\subsection{Elemental Analysis}

Elemental analysis was performed using inductively coupled plasma with optical emission spectrometry (ICP-OES), according to the previously established method [20]. The measurements were performed using Agilent 5100 ICP-OES spectrometer, with continuous wavelength coverage ranging from 166 to $847 \mathrm{~nm}$, equipped with a RACID86 charge injector device detector, pneumatic cross-flow type nebulizer, quartz torch and quartz detector. Instrumental conditions were set as follows: input power of $1200 \mathrm{~W}$, auxiliary gas flow rate of $1.0 \mathrm{~L} / \mathrm{min}$, coolant gas flow rate of $12.0 \mathrm{~L} / \mathrm{min}$, and nebulizer flow rate of $0.7 \mathrm{~L} / \mathrm{min}$. Analyses were performed in triplicate.

Determination of mercury was performed directly from SN leaves and extracts samples using the Milestone DMA- 80 mercury analyzer, with the mercury concentration range of 5-200 ng/g. Limit of detection was $0.15 \mathrm{ng} / \mathrm{g}$, while recovery was $96 \%-110 \%$. Standard solutions were used to create a calibration curve, which described the dependence of intensity on concentration of the standard 
compound $\left(R^{2}>0.999\right)$. Results were expressed as $\mathrm{mg} / \mathrm{L}$ of plant material. Analysis was performed in triplicate.

\subsection{Validation Study}

Validation study of the ICP-OES method was conducted to determine essential analytical parameters concerning the quality of the method and technique. Those parameters are linearity, instrument detection limit (IDL), method detection limit (MDL), accuracy, and precision. Aim of the validation process was to fulfill the requirements given by the method [19]. The calibration standard solutions of lead, cadmium, arsenic, copper, iron, zinc, manganese, nickel, and chromium were in a concentration range of $0.02-1.00 \mathrm{mg} / \mathrm{L}$, potassium and sodium in a concentration range of $0.50-10.00 \mathrm{mg} / \mathrm{L}$, and calcium and magnesium in a concentration range of $0.50-6.00 \mathrm{mg} / \mathrm{L}$. Standard solutions were used to create the calibration curve, which described the dependence of intensity on concentration of the standard compound and to determine the linearity for each element.

Precision, accuracy, IDL, and MDL were determined using commercially available bottled water (Rosa, Serbia) as a blank sample. Spiking of blank samples was performed at two concentration levels (minimal and maximal), $S_{1}$ and $S_{2}$, while analyses were performed in tenfold. From the obtained results IDL and MDL were calculated using the equations given in standard method [19]:

$$
\begin{gathered}
\mathrm{IDL}=3(\mathrm{~S}), \\
\mathrm{MDL}=(\mathrm{t})(\mathrm{S}),
\end{gathered}
$$

where $S$ is standard deviation of the measurements and $t$ is Student's $t$ factor for the confidence level of $99 \%$ for standard deviation determined for $\mathrm{N}-1$ degrees of freedom (3.143 for seven replicates). Accuracy was determined applying the blank sample, while the precision was determined form the repeatability and reproducibility of the method.

\subsection{Statistical Analysis}

XLSTAT (version 2014.5.03, Addinsoft, New York, NY, USA), analysis and statistics add-in for MS Excel and IBM SPSS Statistics for Windows (Version 24.0. Armonk, NY, USA: IBM Corp.) were used for statistical analysis of data. All measurements were performed in triplicate and the results were expressed as means \pm standard deviation (SD). Data were subjected to analysis of variance (ANOVA) for comparison of means, and significant differences between groups were calculated according to Tukey's honestly significant difference (HSD) post hoc test $(p<0.01)$. To examine the possible classification of analyzed samples, principal component analysis (PCA) was applied.

\section{Results and Discussion}

\subsection{Validation of Analysis}

Results of the conducted validation study are presented in Table 1. Linearity for all the elements was high $\left(R^{2}>0.998\right)$, with the exception of calcium $\left(R^{2}=0.9969\right)$, potassium $\left(R^{2}=0.9970\right)$, and magnesium $\left(R^{2}=0.9977\right)$. Precision and accuracy satisfy the required values given by the established method, as well as IDL and MDL, which proved to be quite low indicated the possibility of detection and quantitation of certain elements at trace levels. Data showed that relative standard deviation (RSD) was below $6 \%$ (maximal allowed value is $10 \%$ ), while accuracy was in the range of $87 \%-114 \%$, which fits in the allowed value's range of $100 \% \pm 30 \%$. Overall, the obtained results fulfill the requirements of the established method from the determination of metal and trace elements in water samples [20]. 
Table 1. Obtained values for linearity, limits of detection and quantitation, accuracy, and precision of the applied method.

\begin{tabular}{|c|c|c|c|c|c|}
\hline Element & Linearity & Concentration Range (mg/L) & Calibration Curve & IDL $(\mu \mathrm{g} / \mathrm{L})$ & MDL $(\mu \mathrm{g} / \mathrm{L})$ \\
\hline $\mathrm{Pb}$ & 0.9988 & $0.00-1.00$ & $\mathrm{Y}=1164.63 \mathrm{x}+9.2436$ & 5.8 & 7.0 \\
\hline $\mathrm{Cd}$ & 0.9993 & $0.00-1.00$ & $Y=12733.45 x+40.6606$ & 0.8 & 1.0 \\
\hline As & 0.9994 & $0.00-1.00$ & $Y=557.79 x+4.3289$ & 4.8 & 5.0 \\
\hline $\mathrm{Cu}$ & 0.9998 & $0.00-1.00$ & $Y=34203.24 x+77.3832$ & 0.7 & 1.0 \\
\hline $\mathrm{Fe}$ & 0.9987 & $0.00-1.00$ & $Y=20583.09 x+120.7146$ & 2.5 & 3.0 \\
\hline $\mathrm{Zn}$ & 0.9992 & $0.00-1.00$ & $Y=27447.81 x+92.4606$ & 1.3 & 2.0 \\
\hline Mn & 0.9992 & $0.00-1.00$ & $Y=194570.53 x+733.9341$ & 1.1 & 2.0 \\
\hline $\mathrm{Ni}$ & 0.9983 & $0.00-1.00$ & $Y=4195.05 x+24.0310$ & 2.2 & 3.0 \\
\hline $\mathrm{Cr}$ & 0.9986 & $0.00-1.00$ & $Y=21768.49 x+63.1770$ & 0.8 & 1.0 \\
\hline $\mathrm{K}$ & 0.9970 & $0.00-10.00$ & $Y=1251.7994 x+240.4287$ & 99.9 & 100.0 \\
\hline $\mathrm{Na}$ & 0.9994 & $0.00-10.00$ & $\mathrm{Y}=7787.27 \mathrm{x}+456.4494$ & 30.0 & 30.0 \\
\hline $\mathrm{Ca}$ & 0.9969 & $0.00-6.00$ & $Y=4675.28 x+463240.0555$ & 15.5 & 30.0 \\
\hline $\mathrm{Mg}$ & 0.9977 & $0.00-7.00$ & $Y=362638.66 x+37444.2176$ & 9.0 & 20.0 \\
\hline
\end{tabular}

Intra-day and inter-day precisions are also presented in Table 2 for both spiking levels (Table A1, Appendix A). Results showed that values were lower than $10 \%$ for all elements. This indicated that the establish method is repeatable, with the satisfactory level of the inter-day precision.

Table 2. Accuracy, precision, intra-day, and inter-day precisions of the applied method.

\begin{tabular}{|c|c|c|c|c|}
\hline Element & Accuracy * (\%) & Precision * (RSD, \%) & $\begin{array}{c}\text { Intra-Day } \\
\text { Precision * }(\%)\end{array}$ & $\begin{array}{c}\text { Inter-Day } \\
\text { Precision * }(\%)\end{array}$ \\
\hline \multirow{2}{*}{$\mathrm{Pb}$} & $S_{1}(92-106)$ & $\mathrm{S}_{1} 3.50$ & $\mathrm{~S}_{1} 3.15$ & $\mathrm{~S}_{1} 3.46$ \\
\hline & $\mathrm{S}_{2}(93-102)$ & $\mathrm{S}_{2} 2.90$ & $\mathrm{~S}_{2} 2.78$ & $S_{2} 2.76$ \\
\hline \multirow{2}{*}{$\mathrm{Cd}$} & $\mathrm{S}_{1}(94-112)$ & $\mathrm{S}_{1} 5.80$ & $\mathrm{~S}_{1} 5.74$ & $\mathrm{~S}_{1} 5.56$ \\
\hline & $\mathrm{S}_{2}(94-102)$ & $\mathrm{S}_{2} 2.80$ & $\mathrm{~S}_{2} 2.79$ & $\mathrm{~S}_{2} 2.66$ \\
\hline \multirow[b]{2}{*}{ As } & $\mathrm{S}_{1}(100-114)$ & $\mathrm{S}_{1} 4.70$ & $\mathrm{~S}_{1} 4.48$ & $\mathrm{~S}_{1} 4.54$ \\
\hline & $\mathrm{S}_{2}(96-105)$ & $\mathrm{S}_{2} 2.10$ & $\mathrm{~S}_{2} 3.09$ & $\mathrm{~S}_{2} 3.10$ \\
\hline \multirow{2}{*}{$\mathrm{Cu}$} & $S_{1}(87-98)$ & $\mathrm{S}_{1} 3.70$ & $\mathrm{~S}_{1} 3.71$ & $\mathrm{~S}_{1} 3.59$ \\
\hline & $\mathrm{S}_{2}(99-109)$ & $\mathrm{S}_{2} 3.40$ & $\mathrm{~S}_{2} 3.37$ & $\mathrm{~S}_{2} 3.24$ \\
\hline \multirow{2}{*}{$\mathrm{Fe}$} & $\mathrm{S}_{1}(93-104)$ & $\mathrm{S}_{1} 3.30$ & $\mathrm{~S}_{1} 3.36$ & $\mathrm{~S}_{1} 3.31$ \\
\hline & $\mathrm{S}_{2}(92-104)$ & $\mathrm{S}_{2} 3.70$ & $\mathrm{~S}_{2} 3.63$ & $\mathrm{~S}_{2} 3.57$ \\
\hline \multirow{2}{*}{$\mathrm{Zn}$} & $\mathrm{S}_{1}(88-104)$ & $\mathrm{S}_{1} 5.90$ & $\mathrm{~S}_{1} 5.81$ & $S_{1} 5.61$ \\
\hline & $S_{2}(93-106)$ & $\mathrm{S}_{2} 4.00$ & $\mathrm{~S}_{2} 3.98$ & $\mathrm{~S}_{2} 3.84$ \\
\hline \multirow{2}{*}{$\mathrm{Mn}$} & $\mathrm{S}_{1}(90-110)$ & $S_{1} 5.90$ & $S_{1} 5.90$ & $\mathrm{~S}_{1} 5.87$ \\
\hline & $\mathrm{S}_{2}(94-104)$ & $\mathrm{S}_{2} 2.50$ & $\mathrm{~S}_{2} 2.37$ & $\mathrm{~S}_{2} 2.46$ \\
\hline \multirow{2}{*}{$\mathrm{Ni}$} & $\mathrm{S}_{1}(80-90)$ & $\mathrm{S}_{1} 4.60$ & $\mathrm{~S}_{1} 4.69$ & $\mathrm{~S}_{1} 4.50$ \\
\hline & $\mathrm{S}_{2}(92-106)$ & $\mathrm{S}_{2} 6.50$ & $\mathrm{~S}_{2} 6.51$ & $\mathrm{~S}_{2} 6.21$ \\
\hline \multirow{2}{*}{$\mathrm{Cr}$} & $S_{1}(87-93)$ & $\mathrm{S}_{1} 1.90$ & $\mathrm{~S}_{1} 1.90$ & $\mathrm{~S}_{1} 1.89$ \\
\hline & $S_{2}(96-101)$ & $\mathrm{S}_{2} 1.80$ & $\mathrm{~S}_{2} 1.78$ & $\mathrm{~S}_{2} 1.70$ \\
\hline \multirow{2}{*}{ K } & $\mathrm{S}_{1}(99-106)$ & $\mathrm{S}_{1} 2.60$ & $\mathrm{~S}_{1} 2.53$ & $\mathrm{~S}_{1} 2.49$ \\
\hline & $\mathrm{S}_{2}(97-104)$ & $\mathrm{S}_{2} 2.20$ & $\mathrm{~S}_{2} 2.25$ & $\mathrm{~S}_{2} 2.15$ \\
\hline \multirow{2}{*}{$\mathrm{Na}$} & $\mathrm{S}_{1}(103-108)$ & $\mathrm{S}_{1} 1.80$ & $\mathrm{~S}_{1} 1.80$ & $\mathrm{~S}_{1} 1.75$ \\
\hline & $S_{2}(102-109)$ & $\mathrm{S}_{2} 1.80$ & $\mathrm{~S}_{2} 1.58$ & $\mathrm{~S}_{2} 1.78$ \\
\hline \multirow{2}{*}{$\mathrm{Ca}$} & $S_{1}(94-109)$ & $\mathrm{S}_{1} 3.80$ & $\mathrm{~S}_{1} 3.84$ & $\mathrm{~S}_{1} 3.79$ \\
\hline & $S_{2}(91-103)$ & $\mathrm{S}_{2} 3.00$ & $S_{2} 2.76$ & $\mathrm{~S}_{2} 2.94$ \\
\hline \multirow{2}{*}{$\mathrm{Mg}$} & $\mathrm{S}_{1}(90-101)$ & $\mathrm{S}_{1} 3.50$ & $\mathrm{~S}_{1} 3.49$ & $\mathrm{~S}_{1} 3.35$ \\
\hline & $\mathrm{S}_{2}(93-104)$ & $\mathrm{S}_{2} 4.10$ & $\mathrm{~S}_{2} 4.14$ & $\mathrm{~S}_{2} 3.99$ \\
\hline
\end{tabular}

* Accuracy, precision, inter-day, and intra-day precisions for both spiking levels $\left(\mathrm{S}_{1}\right.$ and $\left.\mathrm{S}_{2}\right)$ are given in the Table, RSD-relative standard deviation.

\subsection{Elemental Profile of SN Extracts}

Obtained elemental profile of the SE, MAC, UAE, and MAE extracts are presented in Table 3. Contents of investigated elements and minerals demonstrated certain diversity among tested extract 
samples. The highest contents of potassium, and magnesium were found in the MAE extract $(965.60 \mathrm{mg} / \mathrm{L}$, and $191.99 \mathrm{mg} / \mathrm{L}$, respectively), while MAC was found to be the richest in calcium and natrium $(464.24 \mathrm{mg} / \mathrm{L}$, and $90.37 \mathrm{mg} / \mathrm{L}$, respectively).

The content of trace elements (microelements) achieved more diversity that in the case of bulk elements. Results showed that highest amounts of iron and zinc were in the UAE extract, while manganese and nickel achieved their maximal yield in the MAE extract. Maximal levels of cooper, chromium, and tin were achieved in UAE. In the case of polluting elements, lead was detected in all four samples, where SE, and UAE contained somewhat higher amount than the MAC, and MAE. Cadmium was detected in a rather trace level in the SE, and UAE extracts. On the other hand, mercury was not detected in any extract sample. Arsenic was quantified only in the SE extract. Possible explanation of arsenic's presence in the SE extract is interference of ethanol during the introduction of the sample into argon plasma.

Table 3. Elements and minerals contents in obtained extracts.

\begin{tabular}{|c|c|c|c|c|c|}
\hline \multirow{3}{*}{ Element } & \multicolumn{4}{|c|}{ Sample } & \multirow{3}{*}{ ANOVA } \\
\hline & SE & MAC & UAE & MAE & \\
\hline & \multicolumn{4}{|c|}{ Content (mg/L) } & \\
\hline & \multicolumn{4}{|c|}{ Macroelement } & $p$ \\
\hline $\mathrm{Na}$ & $60.84 \pm 1.59^{b}$ & $90.37 \pm 0.47^{a}$ & $56.60 \pm 0.09^{c}$ & $46.96 \pm 0.72^{d}$ & $<0.0001$ \\
\hline K & $285.51 \pm 2.06^{\mathrm{d}}$ & $405.19 \pm 0.64^{c}$ & $880.39 \pm 3.39^{b}$ & $965.60 \pm 7.70^{\mathrm{a}}$ & $<0.0001$ \\
\hline $\mathrm{Mg}$ & $12.33 \pm 1.19^{d}$ & $104.43 \pm 0.19^{c}$ & $162.08 \pm 0.52^{b}$ & $191.99 \pm 2.60^{\mathrm{a}}$ & $<0.0001$ \\
\hline $\mathrm{Ca}$ & $29.64 \pm 1.37^{\mathrm{d}}$ & $464.24 \pm 0.24^{\mathrm{a}}$ & $288.88 \pm 0.84^{c}$ & $428.23 \pm 1.93^{b}$ & $<0.0001$ \\
\hline \multicolumn{6}{|c|}{ Microelement } \\
\hline $\mathrm{Fe}$ & $3.53 \pm 0.06^{b}$ & $4.19 \pm 0.93^{b}$ & $8.24 \pm 0.16^{\mathrm{a}}$ & $6.87 \pm 0.02^{a}$ & $<0.0001$ \\
\hline $\mathrm{Cu}$ & $3.16 \pm 0.13^{a}$ & $3.36 \pm 0.99^{a}$ & $2.08 \pm 0.01^{\mathrm{a}}$ & $1.67 \pm 0.01^{\mathrm{a}}$ & 0.0083 \\
\hline $\mathrm{Mn}$ & $0.11 \pm 0.04^{c}$ & $0.27 \pm 0.05^{b}$ & $0.35 \pm 0.01^{b}$ & $0.55 \pm 0.01^{\mathrm{a}}$ & $<0.0001$ \\
\hline $\mathrm{Zn}$ & $0.61 \pm 0.09^{\mathrm{d}}$ & $1.15 \pm 0.03^{c}$ & $2.05 \pm 0.04^{\mathrm{a}}$ & $1.61 \pm 0.04^{b}$ & $<0.0001$ \\
\hline $\mathrm{Cr}$ & $0.20 \pm 0.01^{\mathrm{a}}$ & $0.22 \pm 0.03{ }^{a}$ & $0.01 \pm 0.00^{b}$ & $0.01 \pm 0.00^{b}$ & $<0.0001$ \\
\hline Sn & $1.37 \pm 0.83^{\mathrm{a}}$ & $1.67 \pm 0.05^{\mathrm{a}}$ & $0.53 \pm 0.02^{\mathrm{a}}$ & $0.58 \pm 0.01^{\mathrm{a}}$ & 0.0224 \\
\hline $\mathrm{Ni}$ & $\mathrm{ND}^{*}$ & ND & $0.06 \pm 0.01^{\mathrm{a}}$ & $0.07 \pm 0.02^{\mathrm{a}}$ & 0.4818 \\
\hline \multicolumn{6}{|c|}{ Toxic element } \\
\hline $\mathrm{Pb}$ & $1.36 \pm 0.59^{\mathrm{a}}$ & $0.92 \pm 0.07^{a}$ & $1.13 \pm 0.06^{\mathrm{a}}$ & $0.30 \pm 0.05^{\mathrm{a}}$ & 0.0129 \\
\hline $\mathrm{Cd}$ & $0.01 \pm 0.00$ & ND & $0.01 \pm 0.00$ & ND & - \\
\hline $\mathrm{Hg}$ & ND & ND & ND & ND & - \\
\hline As & $3.64 \pm 0.82$ & ND & ND & ND & - \\
\hline
\end{tabular}

* ND—not detected. The values are presented as mean $\pm \mathrm{SD}$, different superscripts within the same raw indicate significant differences of means, according to Tukey's HSD test $(p<0.01)$.

Based on ANOVA, it could be concluded that there was a significant effect $(p<0.01)$ of the type of extraction on the content of all macro and microelements, except for Ni and Sn. In the case of the toxic elements, the type of extraction had no effect. Significant differences between means were determined by using the Tukey's HSD $(p<0.01)$. These results are presented as lower-case letters in superscript in Table 3. Different letters within the same row indicate significant differences of means $(p<0.01)$.

Regarding the food safety regulations in the Republic of Serbia, allowed amounts of the polluting elements, in this case $\mathrm{Pb}, \mathrm{Cd}$, and As, in alcoholic free refreshing drinks are $0.30,0.03$, and $0.30 \mathrm{mg} / \mathrm{L}$, respectively, while $1.00 \mathrm{mg} / \mathrm{L}$ of As and $2.00 \mathrm{mg} / \mathrm{L}$ are maximal values of these elements in the teas. According the presented results (Table 3), all samples met these requirements and might be used in human nutrition, with the exception of UAE extract, which contained higher level of $\mathrm{Pb}$ then allowed in refreshing drinks. Furthermore, same regulations required contents of $\mathrm{Sn}, \mathrm{Fe}, \mathrm{Cu}$, and $\mathrm{Zn}$ up to $100.00,15.00,5.00$, and $5.00 \mathrm{mg} / \mathrm{L}$, respectively, while the total content of $\mathrm{Zn}, \mathrm{Cu}$, and Fe should be up to $20 \mathrm{mg} / \mathrm{L}$. According to Table 3 , all four extracts met these requirements and might be considered as safe for usage in nutrition. 
Beside meeting requirements of food safety regulations, the obtained results demonstrated the possibility of their usage for other purposes. Thus, according to the dietary reference intake (DRI) established by US Institute of Medicine, estimated intake amounts of elements are given where required daily amounts of $\mathrm{Ca}, \mathrm{Mg}, \mathrm{Na}$, and $\mathrm{K}$ were $1.0-1.3 \mathrm{~g} / \mathrm{d}, 240.0-420.0 \mathrm{mg} / \mathrm{d}, 1.2-1.5 \mathrm{~g} / \mathrm{d}$, and $4.5-4.7 \mathrm{~g} / \mathrm{d}$, respectively. On the other hand, estimated amounts for the $\mathrm{Fe}, \mathrm{Ni}, \mathrm{Zn}, \mathrm{Cu}, \mathrm{Mn}$ and $\mathrm{Cr}$ were 8.0-18.0 $\mathrm{mg} / \mathrm{d}, 0.6-1.0 \mathrm{mg} / \mathrm{d}, 8.0-11.0 \mathrm{mg} / \mathrm{d}, 0.7-1.0 \mathrm{mg} / \mathrm{d}, 1.6-2.3 \mathrm{mg} / \mathrm{d}$, and $20.0-30.0 \mathrm{mg} / \mathrm{d}$, respectively [21]. Estimated amounts depend on the gender and age. Estimated values and determined values on obtained extracts suggested the possibility of their application as a source of essential elements for a human organism.

Another significant field of application of this method might be for the environmental protection, where this plant might be used in the process of phytoremediation. Phytoremediation represents alternative remediation technology based on usage of the plants for removing pollutants and/or render them harmless [22]. Plants used for this purpose are classified according to their tolerance toward metals and accumulation response on contaminated soil into three groups: excluders, indicator plants, and hyper-accumulators. Excluders restrict metal uptake through plant root with the exception in the case of extreme concentrations of the metals. In the case of an indicator plant, accumulated metal concentration is relative to their level in the soil, while hyper-accumulators concentrate the metals regardless of the metal levels in the soil $[23,24]$. A study regarding the heavy metals content in wild plant growing near ironwork in Zenica (Bosnia and Herzegovina) showed that stinging nettle possesses strong affinity toward the metals [25]. Taking those results into account, this plant may be used as a natural remover of polluting elements in soil and underground water, which represents one of the main issues these days in the field of environmental protection. Besides the role of neutralizer, the plant itself may be used as an indicator of elements' presence in a particular area by direct analysis of plant root and leaves or, like in this particular case, by preparing the extracts.

Classification of the investigated extracts (observations) based on their mineral content was done by principal component analysis (PCA). All the parameters given in the Table 3, except for the $\mathrm{Hg}$, were used for the PCA. The first two principal components (PCs) represented $92.19 \%$ of the initial variability of the data (PC1-69.64\% and PC2-22.55\%). Table 4 shows the factor loadings of the PC1 and PC2. PC1 was correlated with the $\mathrm{K}, \mathrm{Mg}, \mathrm{Fe}, \mathrm{Cu}, \mathrm{Mn}, \mathrm{Zn}, \mathrm{Cr}, \mathrm{Sn}, \mathrm{Ni}, \mathrm{Pb}$, and As, while PC2 with $\mathrm{Na}, \mathrm{Ca}$, and $\mathrm{Cd}$ (absolute value of factor loadings $>0.6$ ).

Table 4. Factor loadings of principal component (PC) 1 and 2 obtained by principal component analysis of mineral content of different extracts of the stinging nettle leaves' extracts.

\begin{tabular}{ccc}
\hline \multirow{2}{*}{ Element } & \multicolumn{2}{c}{ Factor Loading } \\
\cline { 2 - 3 } & $\mathbf{P C 1}$ & $\mathbf{P C 2}$ \\
\hline $\mathrm{Na}$ & -0.5924 & $\mathbf{- 0 . 6 7 8 1}$ \\
$\mathrm{K}$ & $\mathbf{0 . 9 9 5 2}$ * & 0.0976 \\
$\mathrm{Mg}$ & $\mathbf{0 . 9 6 4 6}$ & -0.2450 \\
$\mathrm{Ca}$ & 0.5623 & $\mathbf{- 0 . 8 1 5 8}$ \\
$\mathrm{Fe}$ & $\mathbf{0 . 9 1 3 9}$ & 0.2531 \\
$\mathrm{Cu}$ & $\mathbf{- 0 . 9 4 5 0}$ & -0.2677 \\
$\mathrm{Mn}$ & $\mathbf{0 . 9 3 7 5}$ & -0.2706 \\
$\mathrm{Zn}$ & $\mathbf{0 . 8 9 2 0}$ & 0.0429 \\
$\mathrm{Cr}$ & $\mathbf{- 0 . 9 4 3 8}$ & -0.3303 \\
$\mathrm{Sn}$ & $\mathbf{- 0 . 8 8 5 1}$ & -0.4650 \\
$\mathrm{Ni}$ & $\mathbf{0 . 9 7 2 8}$ & 0.2243 \\
$\mathrm{~Pb}$ & $\mathbf{- 0 . 7 1 9 6}$ & 0.4985 \\
$\mathrm{Cd}$ & -0.2665 & $\mathbf{0 . 9 0 2 5}$ \\
$\mathrm{As}$ & $\mathbf{- 0 . 7 4 1 3}$ & 0.5597 \\
\hline * Values in bold are the factor loadings whose absolute value is higher than 0.6.
\end{tabular}

Different extracts of stinging nettle leaves are presented in the PC1 vs. PC2 plane (Figure 1). The extracts were clustered into the three groups based on their mineral content. The first group consists of $\mathrm{UAE}$ and MAE, the second is MAC, and the third is SE (Figure 1). 


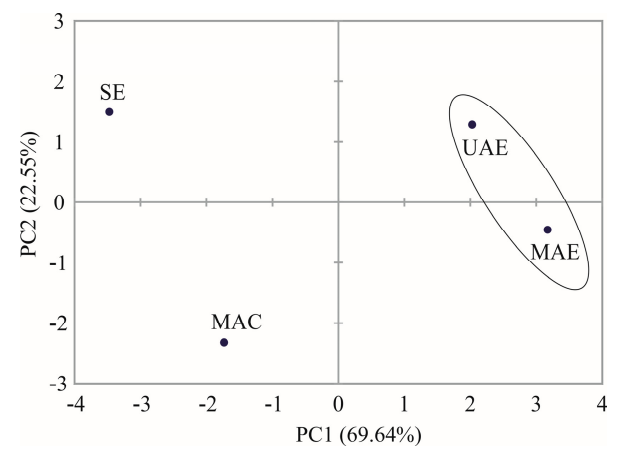

Figure 1. Principal component analysis (PCA): extracts of the extracts in PC1 vs. PC2 plane.

Similarity of the results obtained by the UAE and MAE might be the possible reason for their clustering in the first group. Those two extraction techniques showed better results than the conventional ones.

\section{Conclusions}

Inductively coupled plasma combined with optical emission spectrometry (ICP-OES) was successfully applied, for the analysis of the minerals and elements in different extracts prepared of the stinging nettle leaves. The used method fulfilled all needed requirements and was successfully validated using bottled water. Analysis of extract showed different contents of the minerals and elements depending on applied extraction technique. In microwave-assisted (MAE) extract potassium and magnesium were most abundant bulk elements (macroelements), while natrium and calcium were the most abundant in macerate (MAC). Iron, as one of the most significant element, was the most abundant of all analyzed microelements in all four extracts. Lead and cadmium (toxic elements) were also found in extracts in a rather trace amounts. Such a profile provides possible direct application of $\mathrm{MAE}, \mathrm{UAE}$, and MAC extract in the food industry as a secondary source of minerals.

Author Contributions: Conceptualization, S.Đ.; methodology, S.Đ., and S.P.; validation, S.P., S.S., and S.Š.; formal analysis, S.Đ., S.P., S.S., and S.Š.; investigation, S.Đ., S.S., S.P., and S.Š.; data curation, S.Đ., A.R., and D.M.; writing - original draft preparation, S.Đ. and D.M.; writing-review and editing, S.Đ.; supervision, Z.Z. All authors have read and agreed to the published version of the manuscript.

Funding: This study was financially supported by the Ministry of Education, Science, and Technological Development of the Republic of Serbia.

Conflicts of Interest: The authors declare no conflict of interest.

\section{Appendix A}

Table A1. Concentration of added elements and minerals at the both spiking levels.

\begin{tabular}{ccc}
\hline \multirow{2}{*}{ Element } & \multicolumn{2}{c}{ Additional Concentration $(\mathrm{mg} / \mathbf{L})$} \\
\cline { 2 - 3 } & Spiking Level S1 & Spiking Level S2 \\
\hline $\mathrm{Pb}$ & 0.05 & 0.20 \\
$\mathrm{Cd}$ & 0.01 & 0.10 \\
$\mathrm{As}$ & 0.05 & 0.20 \\
$\mathrm{Cu}$ & 0.02 & 0.20 \\
$\mathrm{Fe}$ & 0.10 & 0.40 \\
$\mathrm{Zn}$ & 0.05 & 0.20 \\
$\mathrm{Mn}$ & 0.01 & 0.10 \\
$\mathrm{Ni}$ & 0.02 & 0.20 \\
$\mathrm{Cr}$ & 0.01 & 0.10 \\
$\mathrm{~K}$ & 5.00 & 20.00 \\
$\mathrm{Na}$ & 5.00 & 20.00 \\
$\mathrm{Ca}$ & 5.00 & 20.00 \\
$\mathrm{Mg}$ & 5.00 & 20.00 \\
\hline
\end{tabular}




\section{References}

1. Orčić, D.; Francišković, M.; Bekvalac, K.; Svirčev, E.; Beara, I.; Lesjak, M.; Mimica-Dukić, N. Quantitative determination of plant phenolics in Urtica dioica extracts by high-performance liquid chromatography coupled with tandem mass spectrometric detection. Food Chem. 2014, 143, 48-53. [CrossRef] [PubMed]

2. Đurović, S.; Zeković, Z.; Šorgić, S.; Popov, S.; Vujanović, M.; Radojković, M. Fatty acid profile of stinging nettle leaves: Application of modern analytical procedures for sample preparation and analysis. Anal. Methods 2018, 10, 1080-1087. [CrossRef]

3. Đurović, S.; Pavlić, B.; Šorgić, S.; Popov, S.; Savić, S.; Pertonijević, M.; Radojković, M.; Cvetanović, A.; Zeković, Z. Chemical composition of stinging nettle leaves obtained by different analytical approaches. J. Funct. Foods 2017, 32, 18-26. [CrossRef]

4. Gül, S.; Demirci, B.; Başer, K.H.C.; Akpulat, H.A.; Aksu, P. Chemical Composition and In Vitro Cytotoxic, Genotoxic Effects of Essential Oil from Urtica dioica L. Bull. Environ. Contam. Toxicol. 2012, 88, 666-671. [CrossRef] [PubMed]

5. Kukric, Z.; Topalic-Trivunovic, L.; Kukavica, B.; Matos, S.; Pavicic, S.; Boroja, M.; Savic, A. Characterization of antioxidant and antimicrobial activities of nettle leaves (Urtica dioica L.). Acta Period. Technol. 2012, 43, 257-272. [CrossRef]

6. Guil-Guerrero, J.L.; Rebolloso-Fuentes, M.M.; Isasa, M.E.T. Fatty acids and carotenoids from stinging nettle (Urtica dioica L.). J. Food Compos. Anal. 2003, 16, 111-119. [CrossRef]

7. Đurović, S.; Šorgić, S.; Popov, S.; Radojković, M.; Zeković, Z. Isolation and GC Analysis of Fatty Acids: Study Case of Stinging Nettle Leaves. In Carboxylic Acid-Key Role in Life Sciences; Badea, G.I., Radu, G.L., Eds.; InTech: London, UK, 2018; pp. 69-83.

8. Bağci, E. Fatty Acid Composition of the Aerial Parts of Urtica Dioica (Stinging Nettle) L. (Urticaceae). In Biodiversity; Şener, B., Ed.; Springer: Boston, MA, USA, 2002; pp. 323-327.

9. Pinelli, P.; Ieri, F.; Vignolini, P.; Bacci, L.; Baronti, S.; Romani, A. Extraction and HPLC analysis of phenolic compounds in leaves, stalks, and textile fibers of Urtica dioica L. J. Agric. Food Chem. 2008, 56, 9127-9132. [CrossRef] [PubMed]

10. Otles, S.; Yalcin, B. Phenolic compounds analysis of root, stalk, and leaves of nettle. Sci. World J. 2012, 2012, 1-12. [CrossRef] [PubMed]

11. Zeković, Z.; Cvetanović, A.; Švarc-Gajić, J.; Gorjanović, S.; Sužnjević, D.; Mašković, P.; Savić, S.; Radojković, M.; Đurović, S. Chemical and biological screening of stinging nettle leaves extracts obtained by modern extraction techniques. Ind. Crops Prod. 2017, 108, 423-430. [CrossRef]

12. Sajfrtová, M.; Sovová, H.; Opletal, L.; Bártlová, M. Near-critical extraction of $\beta$-sitosterol and scopoletin from stinging nettle roots. J. Supercrit. Fluids 2005, 35, 111-118. [CrossRef]

13. Tack, F.; Verloo, M. Metal contents in stinging nettle (Urtica dioica L.) as affected by soil characteristics. Sci. Total Environ. 1996, 192, 31-39. [CrossRef]

14. Kara, D. Evaluation of trace metal concentrations in some herbs and herbal teas by principal component analysis. Food Chem. 2009, 114, 347-354. [CrossRef]

15. Johnson, T.A.; Sohn, J.; Inman, W.D.; Bjeldanes, L.F.; Rayburn, K. Lipophilic stinging nettle extracts possess potent anti-inflammatory activity, are not cytotoxic and may be superior to traditional tinctures for treating inflammatory disorders. Phytomedicine 2013, 20, 143-147. [CrossRef] [PubMed]

16. Gülçin, İ.; Küfrevioğlu, Ö.İ.; Oktay, M.; Büyükokuroğlu, M.E. Antioxidant, antimicrobial, antiulcer and analgesic activities of nettle (Urtica dioica L.). J. Ethnopharmacol. 2004, 90, 205-215. [CrossRef] [PubMed]

17. Ghaima, K.K.; Hashim, N.M.; Ali, S.A. Antibacterial and antioxidant activities of ethyl acetate extract of nettle (Urtica dioica) and dandelion (Taraxacum officinale). J. Appl. Pharm. Sci. 2013, 3, 96-99.

18. Mediterranean Wild Edible Plants; Sánchez-Mata, M.d.C.; Tardío, J. (Eds.) Springer: New York, NY, USA, 2016; ISBN 978-1-4939-3327-3.

19. Mašković, P.Z.; Veličković, V.; Đurović, S.; Zeković, Z.; Radojković, M.; Cvetanović, A.; Švarc-Gajić, J.; Mitić, M.; Vujić, J. Biological activity and chemical profile of Lavatera thuringiaca L. extracts obtained by different extraction approaches. Phytomedicine 2018, 38, 118-124. [CrossRef] [PubMed]

20. US EPA. Method 200.7: Determination of Metals and Trace Elements in Water and Wastes by Inductively Coupled Plasma-Atomic Emission Spectrometry; US EPA: Cincinnati, OH, USA, 1994. 
21. USDA-NAL. Dietary Reference Intakes (DRIs): Estimated Average Requirements. Available online: http: //fnic.nal.usda.gov/dietary-guidance/dietary-reference-intakes/dri-tables (accessed on 25 November 2018).

22. Garbisu, C.; Alkorta, I. Phytoextraction: A cost-effective plant-based technology for the removal of metals from the environment. Bioresour. Technol. 2001, 77, 229-236. [CrossRef]

23. Ghosh, M.; Singh, S.P. A review on phytoremediation of heavy metals and utilization of its by-products. Appl. Ecol. Environ. Res. 2005, 3, 1-18. [CrossRef]

24. Greger, M. Metal Availability and Bioconcentration in Plants. In Heavy Metal Stress in Plants: From Molecules to Ecosystems; Prasad, M.N.V., Hagemeyer, J., Eds.; Springer: New York, NY, USA, 1999; pp. 1-27.

25. Goletić, Š.; Bukalo, E.; Trako, E. Monitoring the Content of Heavy Metals in Soil and Plants in Environment in Ironworks Zenica. In Proceedings of the 7th Reasrch/Expert Conference with International Participation Quality, Vienna, Austria, 20-21 September 2011; pp. 1-4.

C 2020 by the authors. Licensee MDPI, Basel, Switzerland. This article is an open access article distributed under the terms and conditions of the Creative Commons Attribution (CC BY) license (http://creativecommons.org/licenses/by/4.0/). 